\title{
Interaction of DNA Repair Gene XPC With Smoking and Betel Quid Chewing Behaviors of Oral Cancer
}

\author{
CHENG-NAN WU ${ }^{1}$, WEN-SHIN CHANG ${ }^{1,2,3}$, LIANG-CHUN SHIH ${ }^{2,3,4}$, \\ YUN-CHI WANG ${ }^{2,3}$, HSU-TUNG LEE ${ }^{5}$, CHIEN-CHIH YU ${ }^{3,6}$, ZHI-HONG WANG $^{7}$, \\ MEI-CHIN MONG ${ }^{7}$, TE-CHUN HSIA ${ }^{3}$, CHIA-WEN TSAI ${ }^{1,2,3}$ and DA-TIAN BAU ${ }^{2,3,8}$ \\ ${ }^{1}$ Department of Medical Laboratory Science and Biotechnology, \\ Central Taiwan University of Science and Technology, Taichung, Taiwan, R.O.C.; \\ ${ }^{2}$ Graduate Institute of Biomedical Sciences, China Medical University, Taichung, Taiwan, R.O.C.; \\ ${ }^{3}$ Terry Fox Cancer Research Laboratory, Department of Medical Research, \\ China Medical University Hospital, Taichung, Taiwan, R.O.C.; \\ ${ }^{4}$ Department of Otorhinolaryngology, China Medical University Hospital, Taichung, Taiwan, R.O.C.; \\ ${ }^{5}$ Cancer Prevention Center, Taichung Veterans General Hospital, Taichung, Taiwan, R.O.C.; \\ ${ }^{6}$ School of Pharmacy, China Medical University, Taichung, Taiwan, R.O.C.; \\ ${ }^{7}$ Department of Food Nutrition and Health Biotechnology, Asia University, Taichung, Taiwan, R.O.C.; \\ ${ }^{8}$ Department of Bioinformatics and Medical Engineering, Asia University, Taichung, Taiwan, R.O.C.
}

\begin{abstract}
Background/Aim: Xeroderma pigmentosum complementation group $C(X P C)$ is reported to play important roles in DNA integrity and genomic instability, however, the contribution of XPC to oral carcinogenesis is largely uncertain. Therefore, we aimed at examining the contribution of XPC genotypes to oral cancer. Materials and Methods: The genotypes of XPC rs2228001 and rs2228000 were examined among 958 oral cancer patients and 958 control subjects by polymerase chain reaction-restriction fragment length polymorphism methodology and corresponding DNA repair capacity was checked. Results: First, the percentages of XPC rs2228001 AC and CC were higher among oral cancer patients than controls. Second, no significant association was observed regarding XPC rs2228000. Third, there was a synergistic influence of smoking and betel quid chewing behaviors and XPC rs2228001 genotype on oral cancer risk. Last, functional
\end{abstract}

This article is freely accessible online.

Correspondence to: Da-Tian Bau, Chia-Wen Tsai, Terry Fox Cancer Research Laboratory, Department of Medical Research, China Medical University Hospital, 2 Yuh-Der Road, Taichung, 404 Taiwan, R.O.C. Tel: +886 422053366 ext. 5805, e-mail: datian@mail.cmuh.org.tw; artbau2@gmail.com

Key Words: Betel quid chewing, genotype, oral cancer, polymorphism, smoking, Taiwan, XPC. experiments showed DNA repair capacity was lower for $A C / C C$ carriers than AA carriers. Conclusion: XPC rs2228001 C allele, which was associated with decreased DNA repair capacity, may interact with smoking and betel quid chewing behaviors on oral cancer risk.

Oral cancer is the tenth most common cancer worldwide, and Taiwan has one of the highest incidences (1). Based on the most updated annual statistics from the government, oral cancer is of the fourth death-causing cancers among Taiwanese males (2). Uniquely, betel quid chewing, in addition to cigarrete smoking and alcohol drinking, has been identified as an effective environmental factor to oral cancer risk in Taiwan (3). The Taiwan government has embarked in population screen searching for the oral cancer candidates for early cure and medication to lower its incidence, however, the death rate and incidence of oral cancer were still high. Therefore, novel predictors for oral cancer risk are still needed.

There are five major DNA repair systems, consisting of more than 130 genes, and teaming up to maintain the stability and integrity of the human genome. Among them, the nucleotide excision repair (NER) system is in charge of removing DNA crosslinks, bulky adducts, alkylating DNA adducts, oxidative DNA adducts and thymidine dimers (4-6). In NER machinery, four major steps (adduct recognition, lesion DNA incision, gapped DNA fulfilling and ligation) and several core players, including xeroderma pigmentosum complementation group C (XPC)-RAD23B, play critical roles as key enzymes $(4,5)$ Theoretically, subtle genetic 
variation on the NER genes may change DNA repair capacity and thus interfere critically in tumorigenesis (7). However, little is revealed in the literature.

$X P C$ gene is one of the major genes in the NER system and plays a role in very early steps of NER (8). Molecular studies have revealed that XPC may interact with RAD23B forming the XPC-RAD23B, and playing an important role in the DNA adduct recognition and initiation of the NER machinery $(5,8,9)$. In the overall NER machinery, the DNA adduct recognition is thought to be the rate-limiting step (9). This may give us a rationale that it is towards figuring out a predictor on $X P C$ gene for carcinogenesis.

Based on the National Center for Biotechnology Information website, there are more than one hundred coding-region single nucleotide polymorphisms (SNPs) for the $X P C$ gene. Among all the identified SNPs of XPC gene, two polymorphisms Ala499Val (rs2228000) and Lys939Gln (rs2228001) have been mostly investigated. The rs2228000 located in the domain interacting with RAD23B, while the rs2228001 located in the domain interacting with TFIIH. In the literature, many studies have examined the association of rs2228001 (10-14) and/or rs2228000 (15-18) genotypes of $X P C$ with the risk of cancers, but conclusions were inconsistent.

In 2006, Kietthubthew and colleagues firstly investigated the contribution of genotypes of XPC to oral squamous cell carcinoma in a population of 106 cases and 164 controls (19). They found that XPC rs2228001 may not contribute to oral cancer susceptibility, and no joint effect with environmental factors including smoking, alcohol drinking or betel quid chewing (19). In 2007, Wang and colleagues provided evidence showing that XPC rs2228000 genotypes have conferred a protective effect on oral cancer susceptibility, evident in older individuals, women, ever smokers, and never drinkers (20). In 2019, Senghore and colleagues found that the TT genotype at $X P C$ rs2228000 increased the risk of poor overall survival at borderline significance compared to the $\mathrm{CC}+\mathrm{CT}$ genotypes (HR=1.86, 95\% CI=0.97-3.56), while $X P C$ rs 2228000 or $X P C$ rs2228001 genotypes could not serve as good predictors for oral cancer susceptibility (21). Based on the limited literature on $X P C$ and oral cancer, we are keen to assess whether rs2228000 and rs2228001 polymorphisms of XPC are associated with the risk of oral cancer in Taiwan. Additionally, we aimed to investigate the joint effect of betel quid chewing behaviors and XPC genotypes on oral cancer susceptibility. Furthermore, the genotype-phenotype pilot study investigating the DNA repair capacity will be firstly conducted.

\section{Materials and Methods}

Recruited Taiwanese oral cancer cases and controls. In brief, 958 oral cancer patients had been recruited at the China Medical University Hospital (22-24). The frequencies of their demographic characteristics
Table I. Demographic characteristics of the 958 oral cancer patients and 958 non-cancer healthy controls.

\begin{tabular}{lccc}
\hline Characteristics & $\begin{array}{c}\text { Controls } \\
(\mathrm{n}=958)\end{array}$ & $\begin{array}{c}\text { Cases } \\
(\mathrm{n}=958)\end{array}$ & $p$-Value \\
\hline Age (years) & $56.8 \pm 8.7$ & $56.4 \pm 7.5$ & $0.3755^{\mathrm{a}}$ \\
Gender, $\mathrm{n}(\%)$ & $728(76.0 \%)$ & $728(76.0 \%)$ & $1.0000^{\mathrm{b}}$ \\
Male & $230(24.0 \%)$ & $230(24.0 \%)$ & \\
Female & & & \\
Personal behaviors, $\mathrm{n}(\%)$ & $668(69.7 \%)$ & $718(74.9 \%)$ & $\mathbf{0 . 0 1 0 7}^{\mathrm{b}}$ \\
Cigarette smokers & $642(67.0 \%)$ & $684(71.4 \%)$ & $\mathbf{0 . 0 3 7 7}^{\mathrm{b}}$ \\
Alcohol drinkers & $508(53.0 \%)$ & $773(80.7 \%)$ & $\mathbf{< 0 . 0 0 0 1}$ \\
Betel quid chewers & & $397(41.4 \%)$ & \\
Primary tumor site, $\mathrm{n}(\%)$ & & $356(37.2 \%)$ & \\
Tongue & & $39(4.1 \%)$ & \\
Buccal mucosa & & $33(3.4 \%)$ & \\
Mouth floor & & $29(3.0 \%)$ & \\
Retromolar trigone & & $27(2.8 \%)$ & \\
Alveolar ridge & & $39(4.1 \%)$ & \\
Palate & & $38(4.0 \%)$ & \\
Lip & & & \\
Other & & & \\
\hline
\end{tabular}

SD: Standard deviation; 'Based on Student's $t$-test; bBased on Chisquare test. Significant $p$-Values $(p<0.05)$ are shown in bold.

including age, gender, personal behaviors and tumor sites were summarized in Table I. The study had been approved and supervised under the Institutional Review Board (DMR101-IRB1-306).

Oral cancer XPC genotyping methodology. DNA from all participants was processed in typical polymerase chain reaction (PCR) processes as in our previous papers (25-27). The sequences of designed forward and reverse primers, corresponding restriction enzymes (New England BioLabs, Ipswich, MA, USA) and sizes of PCR products after enzyme digestion for oral cancer XPC genotyping identification are shown in Table II.

XPC mRNA expression pattern. Thirty-five surgically removed oral cancer tissue samples obtained from tumor sites were collected. The patients were all non-smokers, non-alcohol-drinkers, and non-betel quid chewers. Glyceraldehyde 3-phosphate dehydrogenase (GAPDH) was used as an internal standard. The primers for $X P C$ mRNA were forward 5'-GACAAGCAGGAGAAGGCAAC-3' and reverse 5'GGTTCGGAATCCTCATCAGA-3', respectively. The primers for GAPDH were forward 5'-GAAATCCCATCACCATCTTCCAGG-3' and reverse 5'-GAGCCCCAGCCTTCTCCATG-3', respectively. Fold changes were normalized using GAPDH, and each experiment was carried out at least thrice (28-30).

XPC protein expression pattern. As mentioned above, the tissue specimens from oral cancer were spontaneously prepared for western blotting. Briefly, after $10 \%$ sodium dodecyl sulphate polyacrylamide gel electrophoresis (SDS-PAGE) gel, and transferring to a nitrocellulose membrane (BioRad Laboratories, Hercules, CA, USA), the membrane was blocked with mouse monoclonal anti-human XPC antibody $(1: 1,000$; Thermo Fisher Scientific, Waltham, MA, USA), and then with horseradish 
Table II. Sequences of the designed primers, corresponding endonucleases and fragments identifications for genotyping of XPC rs2228000 and rs 2228001

\begin{tabular}{llcc}
\hline Polymorphic site & 5' to 3' primer sequences & Endonucleases & Allelic subtypes and product size (bp) \\
\hline rs2228000 & GTGCCCGTATCTGTTGGTCT & Pvu II & C: $121+21$ \\
rs2228001 & TAATATCGGGGCTCACCCTG & T: 142 \\
& GGAGGTGGACTCTCTTCTGA & Pvu II & A: 765 \\
TAGATCCCAGCAGATGACC & & C: $585+180$ \\
\hline
\end{tabular}

Table III. Distribution of XPC rs2228000 and rs2228001 genotypes among the 958 oral cancer patients and 958 non-cancer healthy controls.

\begin{tabular}{|c|c|c|c|c|c|c|}
\hline \multirow[t]{2}{*}{ Genotype } & \multicolumn{2}{|c|}{ Cases } & \multicolumn{2}{|c|}{ Controls } & \multirow[t]{2}{*}{ OR $(95 \% \mathrm{CI})$} & \multirow[t]{2}{*}{$p$-Value } \\
\hline & $\mathrm{n}$ & $\%$ & $\mathrm{n}$ & $\%$ & & \\
\hline \multicolumn{7}{|l|}{ rs2228000 } \\
\hline $\mathrm{CC}$ & 383 & $40.0 \%$ & 389 & $40.6 \%$ & 1.00 (reference) & \\
\hline $\mathrm{CT}$ & 450 & $47.0 \%$ & 454 & $47.4 \%$ & $1.01(0.83-1.22)$ & 0.9455 \\
\hline TT & 125 & $13.0 \%$ & 115 & $12.0 \%$ & $1.10(0.83-1.48)$ & 0.5035 \\
\hline $\mathrm{CT}+\mathrm{TT}$ & 575 & $60.0 \%$ & 569 & $59.4 \%$ & $1.03(0.86-1.23)$ & 0.7799 \\
\hline$P_{\text {trend }}$ & & & & & & 0.7862 \\
\hline$P_{\mathrm{HWE}}$ & & & & & & 0.3182 \\
\hline \multicolumn{7}{|l|}{ rs2228001 } \\
\hline AA & 381 & $39.8 \%$ & 406 & $42.4 \%$ & 1.00 (reference) & \\
\hline $\mathrm{AC}$ & 453 & $47.3 \%$ & 448 & $46.8 \%$ & $1.08(0.89-1.30)$ & 0.4444 \\
\hline $\mathrm{CC}$ & 124 & $12.9 \%$ & 104 & $10.8 \%$ & $1.27(0.95-1.71)$ & 0.1121 \\
\hline $\mathrm{AC}+\mathrm{CC}$ & 577 & $60.2 \%$ & 552 & $57.6 \%$ & $1.11(0.93-1.34)$ & 0.2457 \\
\hline$P_{\text {trend }}$ & & & & & & 0.2758 \\
\hline$P_{\mathrm{HWE}}$ & & & & & & 0.2336 \\
\hline
\end{tabular}

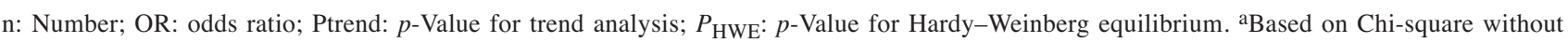
Yate's correction test.

peroxidase-conjugated goat anti-mouse IgG secondary antibody (Chemicon, Temecula, CA, USA). The ECL density was quantified using a computer-assisted imaging analysis system (GeneTools Match software; Syngene) (31).

DNA repair capacity measurement. About ten milliliters of peripheral venous blood was collected from oral cancer patients into heparinized tubes, mixed 1:1 with RPMI 1640 medium (Sigma-Aldrich) and centrifuged at $1200 \mathrm{rpm}$ for $30 \mathrm{~min}$. Isolated peripheral blood mononuclear cells were counted and their viability was checked for their viability (higher than 95\%) and ready for UVC-irradiated comet assay (32). Cells were irradiated with UVC $40 \mathrm{~J} / \mathrm{m}^{2}$ with UV light crosslinker (Spectrolinker XL-1000. Spectronics Co., Westburg, NY, USA) at a dose-rate of $0.5 \mathrm{~W} / \mathrm{m}^{2}$ and the Comet assay was performed immediately (R0) and $6 \mathrm{~h}$ later (R6). UV endonuclease V was used for the removal of cyclobutane pyrimidine dimers and 50 randomly selected cells from two parallel slides per person. For each person, (the average comet moment at R0 - the average comet moment R6)/the average comet moment at R0) * 100\%=individual repair capacity. The standard $100 \%$ was set as the average of those carrying AA genotype of XPC rs2228001.
Statistical analysis. The Student's t-test was applied to compare the distribution of ages between the case and control groups. Pearson's chi-square test had been used to compare the distribution of the $X P C$ rs2228000 and rs2228001 genotypes among the subgroups, and also to evaluated the possible interaction among the smokers, non-smokers, alcohol drinkers, non-alcohol drinkers, betel quid chewers, non-betel quid chewers. The association between the XPC rs 2228000 and rs2228001 genotypes and oral cancer risk had been investigated using odds ratios (ORs) and their corresponding $95 \%$ confidence intervals (CIs). Any difference with $p<0.05$ was taken as statistically significant.

\section{Results}

The demographic characteristics for the 1,916 Taiwan participants (958 oral cancer cases and 958 non-cancer healthy controls) are summarized in Table I. First, since we matched the cases and control by age and gender, there is no difference in respect to these aspects (both $p>0.05$ ). Second, as for smoking, alcohol drinking and betel quid chewing, 
Table IV. Distributions of XPC rs2228000 and rs2228001 genotypes among the 958 oral cancer patients and 958 non-cancer healthy controls.

\begin{tabular}{|c|c|c|c|c|c|c|}
\hline Allele & Cases & $\%$ & Controls & $\%$ & OR $(95 \% \mathrm{CI})$ & $p$-Value ${ }^{\mathrm{a}}$ \\
\hline \multicolumn{7}{|l|}{ rs 2228000} \\
\hline Allele C & 1216 & $63.5 \%$ & 1232 & $64.3 \%$ & 1.00 (reference) & \\
\hline Allele T & 700 & $36.5 \%$ & 684 & $35.7 \%$ & $1.04(0.91-1.18)$ & 0.5905 \\
\hline \multicolumn{7}{|l|}{ rs2228001 } \\
\hline Allele A & 1215 & $63.4 \%$ & 1260 & $65.8 \%$ & 1.00 (reference) & \\
\hline Allele C & 701 & $36.6 \%$ & 656 & $34.2 \%$ & $1.11(0.97-1.27)$ & 0.1285 \\
\hline
\end{tabular}

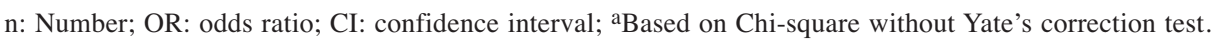

there are different distributions between the oral cancer and control cohorts, respectively (all $p<0.05$, Table I).

In Table III, we summarize the results of the distributions of genotypic frequencies of the two XPC SNPs, rs2228000 and rs2228001. First, the allelic frequencies in XPC rs2228000 and rs2228001 of the control group fitted well with the HardyWeinberg equilibrium (both $p>0.05$ ). Second, in $X P C$ rs2228000, there was no significant difference between the case and control groups (Table III, top panel, $p$ for trend $>0.05$ ). Last, concerning XPC rs2228001, although there was no significant difference between the case and control groups with regards to the frequency of the AA, AC and CC genotypes (Table III, bottom panel, $p$ for trend $>0.05$ ), it seemed that both $\mathrm{AC}$ and $\mathrm{CC}$ genotypes were higher in the case group (47.3 and $12.9 \%$ ) than the control group (46.8 and $10.8 \%$ ), respectively (Table III, bottom panel). Overall, it can be seen that not only the XPC rs2228000 polymorphism, but also XPC rs2228001 failed to serve as a predictor of oral cancer risk in Taiwan.

We also examined the distribution of the allelic frequencies for $X P C$ rs2228000 and rs2228001, and results are presented in Table IV. The variant $\mathrm{T}$ allele in $X P C$ rs2228000 was not to be associated with an increased oral cancer risk $(\mathrm{OR}=1.04,95 \% \mathrm{CI}=0.91-1.18, p=0.5905)$ (Table $\mathrm{IV}$, top panel). At the same time, the variant $\mathrm{C}$ allele of $X P C$ rs2228001 was not associated with and increased risk of oral cancer either (Table IV, bottom panel).

Since oral cancer has been found to be closely related with the consumption of cigarrete, alcohol and betel quid in Taiwan, it is important to investigate the interaction between $X P C$ rs2228000 and rs2228001 genotypes with these risk behaviors and whether such an interaction poses an even higher risk for getting oral cancer. Interestingly, there is a significant joint effect of XPC rs2228001 with smoking habits on oral cancer, which is shown in Table V $(p=0.0283)$. At the same time, there was no higher risk for non-smokers (Table $\mathrm{V}$, bottom panel). However, there was no significant difference for XPC rs2228000 among smokers or nonsmokers (data not shown). Next, we stratified the age- and gender-matched oral cancer patients and controls according to their alcohol drinking behaviors, and results are shown in Table VI. We found that there was no higher risk for either drinkers or non-drinkers for XPC rs2228001 (Table VI) and $X P C$ rs2228000 (data not shown). Last, we also stratified the age- and gender-matched oral cancer patients and controls according to their betel quid chewing behaviors and analyzed their joint effect (Table VII). We found that there is a significant joint effect of XPC rs2228001 with a personal habit of betel quid chewing on oral cancer $(p=0.0300$, Table VII top panel). However, there was no altered oral cancer risk for non-betel quid chewers with the variant $\mathrm{AC}$ or $\mathrm{CC}$ genotypes in XPC rs2228001 ( $p=0.1480$ ) (Table VII, bottom panel). There was no higher risk for either betel quid chewers or non-chewers as for XPC rs2228000 (data not shown).

We examined the expression levels of XPC mRNA and protein according to their XPC rs2228001 genotypes and the results are presented in Figures 1 and 2. There is a slight trend that CC genotypes at XPC rs2228001 have lower expression of XPC at protein and mRNA levels, while it did not reach a statistical significant level $(p=0.0919$, Figure 1A). After the combination of $\mathrm{AC}$ with $\mathrm{CC}$, it still did not reach a statistical significance compared with AA genotype ( $p=0.1355$, Figure 1B). Interestingly, compared to those with wild-type AA genotype, oral cancer patients with variant $\mathrm{CC}$ genotype was of lower protein level ( $p=0.0106$, Figure $2 \mathrm{~B}$ ). After the combination of $\mathrm{AC}$ with $\mathrm{CC}$, it still reached a statistical significance compared with AA genotype ( $p=0.0376$, Figure 2C).

We examined the DNA repair capacity of oral cancer patients with different $X P C$ genotypes and results are shown in Figure 3. Thirty- oral cancer patients were collected. They were all non-smokers, non-alcohol drinkers and non-betel quid chewers. According to their genotyping results, there is 15, 14 and 6 individuals carrying $\mathrm{AA}, \mathrm{AC}$ and $\mathrm{CC}$ genotypes at XPC rs2228001. Based on these pilot results, those with CC genotype at XPC rs2228001 were of lower DNA repair capacity than those of wild-type AA genotype ( $p=0.0306$, Figure $3 \mathrm{~A})$. After the combination of $\mathrm{AC}$ with $\mathrm{CC}$, the group was still statistically lower than AA genotype ( $p=0.0279$, Figure $3 \mathrm{~B})$. 
Table V. Distribution of XPC rs2228001 genotypes among the 958 oral cancer patients and 958 non-cancer healthy controls after stratification by smoking status.

\begin{tabular}{|c|c|c|c|c|}
\hline \multirow[t]{2}{*}{ Smoking status } & \multicolumn{3}{|c|}{$X P C$ rs2228001 genotype } & \multirow[b]{2}{*}{$p$-Value } \\
\hline & $\mathrm{AA}(\%)$ & $\mathrm{AC}(\%)$ & $\mathrm{CC}(\%)$ & \\
\hline \multicolumn{5}{|l|}{ Smokers } \\
\hline Controls & $287(43.0 \%)$ & $312(46.7 \%)$ & $69(10.3 \%)$ & \\
\hline Patients & $276(38.4 \%)$ & $336(46.8 \%)$ & $106(14.8 \%)$ & $0.0283 *$ \\
\hline \multicolumn{5}{|l|}{ Non-smokers } \\
\hline Controls & $119(41.0 \%)$ & $136(46.9 \%)$ & $35(12.1 \%)$ & \\
\hline Patients & $105(43.7 \%)$ & $117(48.8 \%)$ & $18(7.5 \%)$ & 0.2160 \\
\hline
\end{tabular}

aBased on Chi-square without Yate's correction test; the significant $p$-Value and odds ratio are bolded and marked with a star $(*)$.

Table VI. Distribution of XPC rs2228001 genotypes among the 958 oral cancer patients and 958 non-cancer healthy controls after stratification by alcohol drinking status.

\begin{tabular}{|c|c|c|c|c|}
\hline \multirow[t]{2}{*}{ Drinking status } & \multicolumn{3}{|c|}{$X P C$ rs2228001 genotype } & \multirow[b]{2}{*}{$p$-Value } \\
\hline & $\mathrm{AA}(\%)$ & $\mathrm{AC}(\%)$ & $\mathrm{CC}(\%)$ & \\
\hline \multicolumn{5}{|l|}{ Drinkers } \\
\hline Controls & $274(42.7 \%)$ & $299(46.6 \%)$ & $69(10.7 \%)$ & \\
\hline Patients & $273(39.9 \%)$ & $323(47.2 \%)$ & $88(12.9 \%)$ & 0.3870 \\
\hline \multicolumn{5}{|l|}{ Non-drinkers } \\
\hline Controls & $132(41.8 \%)$ & $149(47.1 \%)$ & $35(11.1 \%)$ & \\
\hline Patients & $108(39.4 \%)$ & $130(47.5 \%)$ & $36(13.1 \%)$ & 0.6970 \\
\hline
\end{tabular}

aBased on Chi-square without Yate's correction test.

Table VII. Distribution of XPC rs2228001 genotypes among the 958 oral cancer patients and 958 non-cancer healthy controls after stratification by betel quid chewing status.

\begin{tabular}{|c|c|c|c|c|}
\hline \multirow[t]{2}{*}{ BQ status } & \multicolumn{3}{|c|}{$X P C$ rs2228001 genotype } & \multirow[b]{2}{*}{$p$-Value } \\
\hline & $\mathrm{AA}(\%)$ & $\mathrm{AC}(\%)$ & $\mathrm{CC}(\%)$ & \\
\hline \multicolumn{5}{|l|}{ Chewers } \\
\hline Controls & $223(43.9 \%)$ & $236(46.5 \%)$ & $49(9.6 \%)$ & \\
\hline Patients & $304(39.3 \%)$ & $358(46.3 \%)$ & $111(14.4 \%)$ & $0.0300 *$ \\
\hline \multicolumn{5}{|c|}{ Non-chewers } \\
\hline Controls & $183(40.7 \%)$ & $212(47.1 \%)$ & $55(12.2 \%)$ & \\
\hline Patients & $77(41.6 \%)$ & $95(51.4 \%)$ & $13(7.0 \%)$ & 0.1480 \\
\hline
\end{tabular}

BQ: Betel quid. aBased on Chi-square without Yate's correction test; the significant $p$-Value and odds ratio are bolded and marked with a star $(*)$.

\section{Discussion}

Certain points of the study must be underlined. First, we examined the contribution of XPC genotypes to elevated oral cancer risk among an extremely large population of
Taiwanese, containing 958 oral cancer patients and 958 age, gender-matched healthy controls. The results showed that $X P C$ rs2228001 C allele carriers were of a non-significant higher risk for oral cancer, while this significance was not found for the XPC rs2228000 genotypes (Table IV). Second, 
A

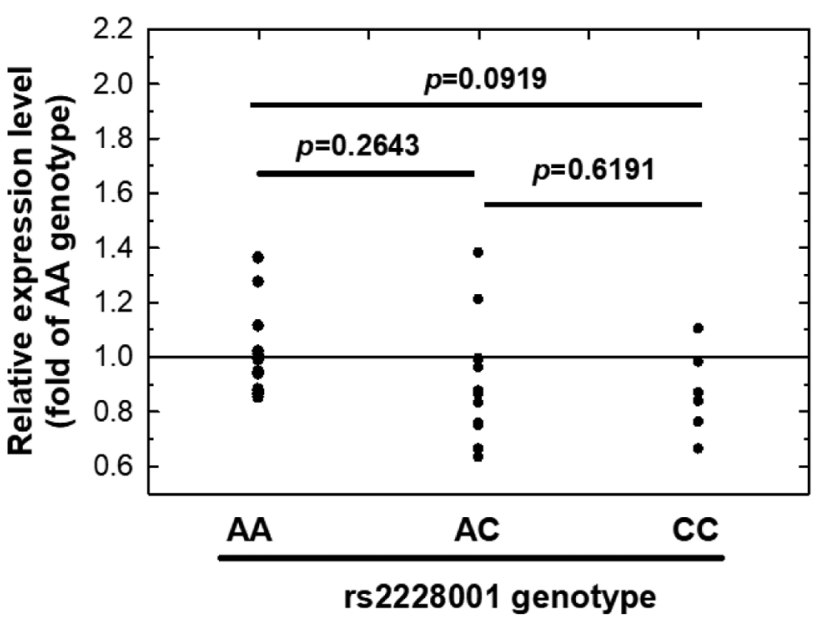

B

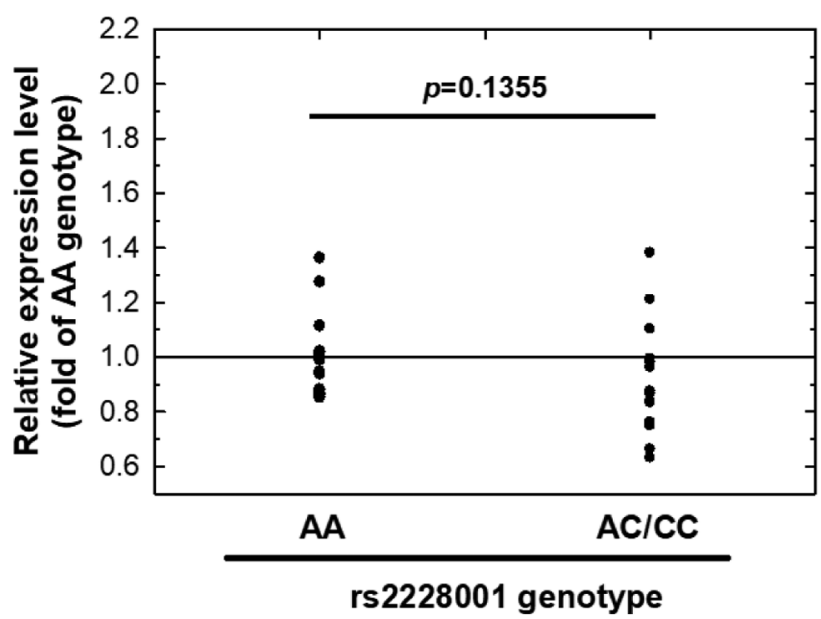

Figure 1. Analysis of XPC mRNA expression levels among oral cancer patients. (A) Quantitative RT-PCR of oral cancer tissue samples for the three genotypes of XPC rs2228001 was performed. GAPDH was used as an internal control. Fold changes were normalized using the levels of GAPDH expression, and each assay was performed at least in triplicate. (B) The AC and CC groups were combined and compared with the AA group.

A

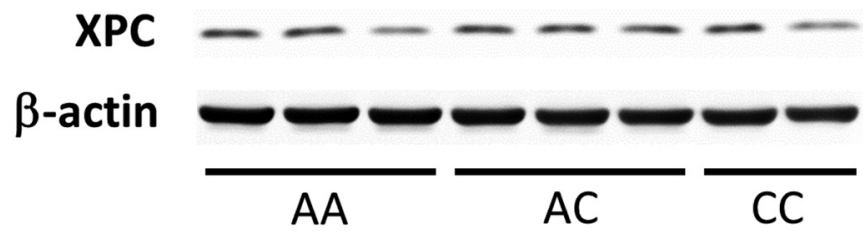

B

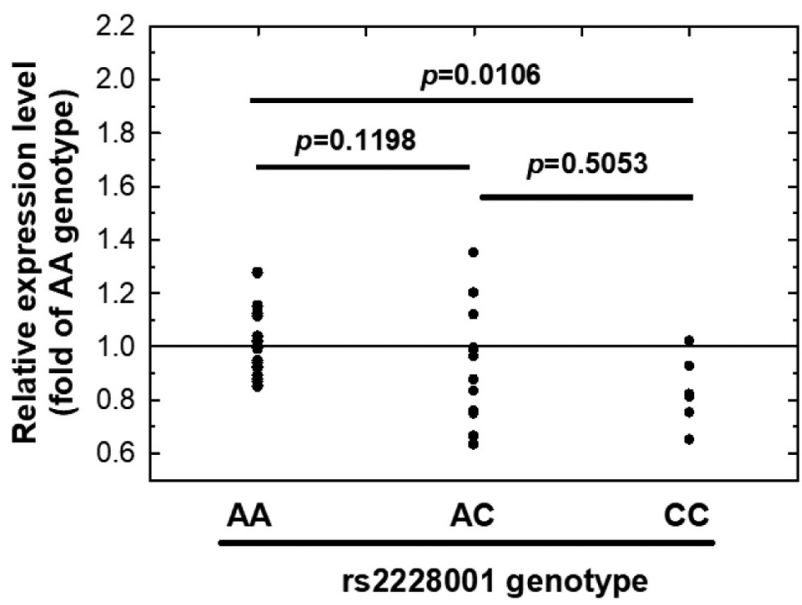

C

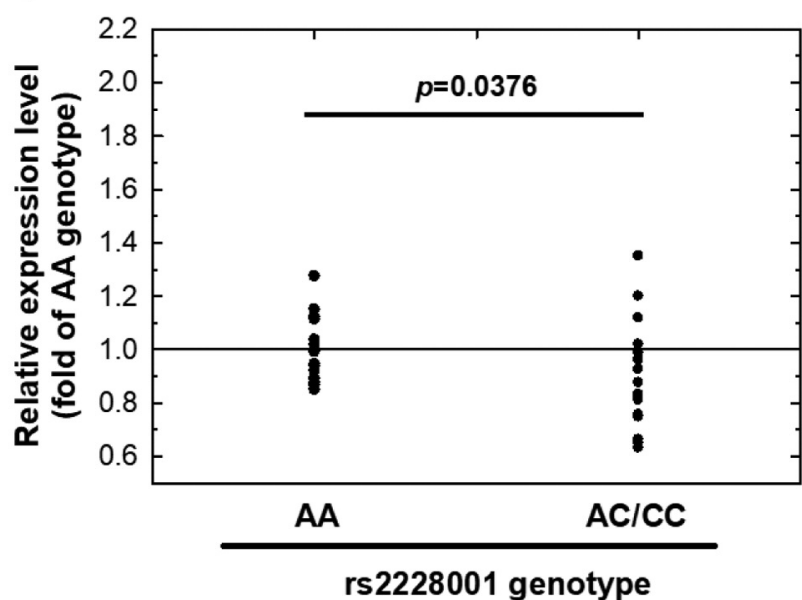

Figure 2. The expression levels of XPC in oral cancer tissues from patients with different XPC rs2228001 genotypes. (A) Western blot analysis of XPC expression in tumor tissues from cases with AA, AC, and CC XPC rs2228001 genotypes. (B) Quantification of the western blot data from (A). $\beta$-actin was used as the loading control. Data were averaged from at least three repeat analyses of the tissues of each group, with $15 \mu \mathrm{g}$ total sample protein for each lane. (C) The AC and CC groups were combined and compared with the AA group. 
A

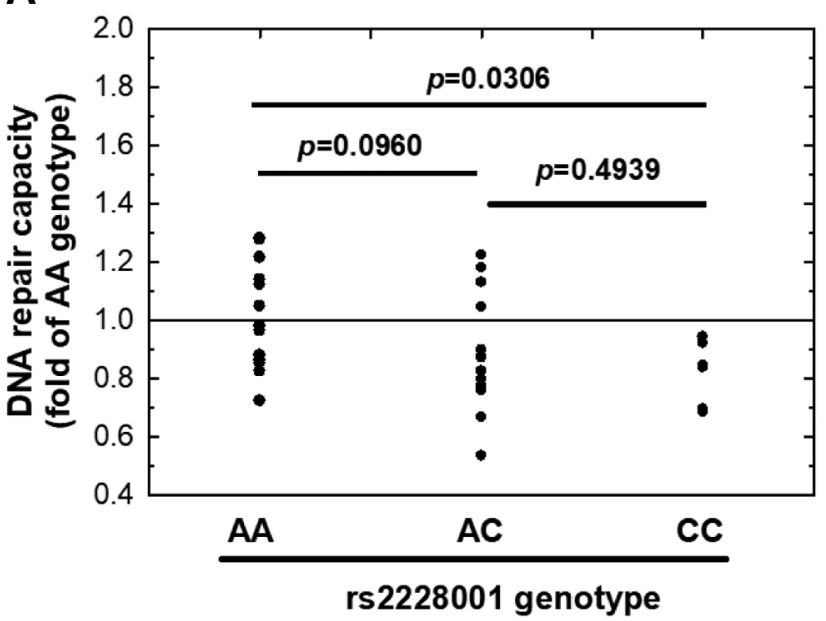

B

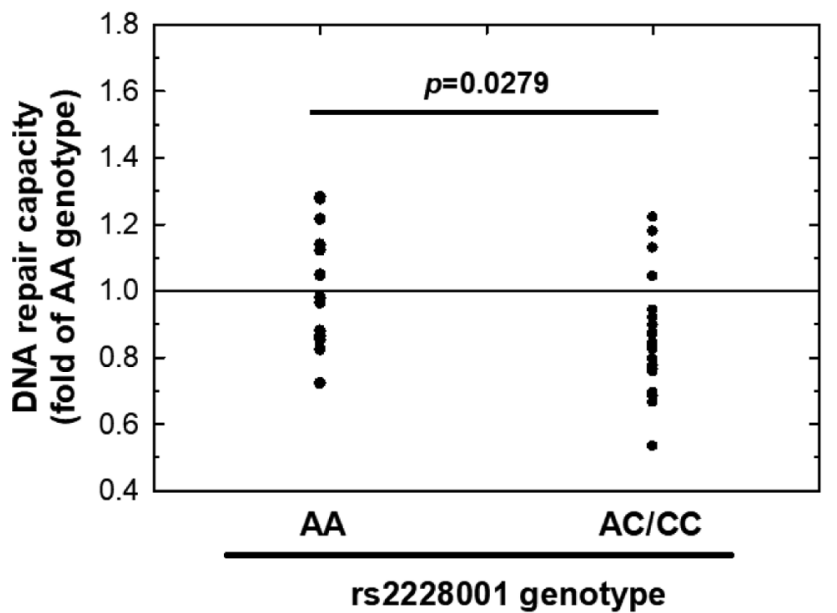

Figure 3. The DNA repair capacity of oral cancer patient cells with different XPC rs2228001 genotypes. (A) DNA repair capacity from cases with $A A, A C$, and CC XPC rs2228001 genotypes. (B) The AC and CC groups were combined and compared to the AA group.

the variant genotypes of $X P C$ rs2228001 were associated with an elevated oral cancer risk in the group of smokers and betel quid chewers, but not in the non-smoker or non-chewer groups (Tables V and VII). Third, the mRNA and protein levels were first investigated using the samples from oral cancer patients (Figures 1 and 2). Last but not the least, we found that the DNA repair capacity was lower in cells from patients carrying variant genotypes at XPC rs2228001 than those carrying wild-type (Figure 3 ).

The novel findings showed that the variant AC and CC genotypes at XPC rs2228001 cannot serve as a good biomarker for oral cancer risk prediction in Taiwan. On the contrary, these results can help us predict whether a smoker or betel quid chewer has a higher risk for oral cancer. An increased risk has also been seen in several types of cancers, including breast $(33,34)$, lung $(35)$, bladder $(11,36)$, colorectal (37), prostate (38), gastric cancer (39) in various populations. Notably, the role of XPC in oral cancer is still lacking, and we are the first to investigate its expression levels of mRNA and protein. Most of all, we have the access to measure the DNA repair capacity in oral cancer patients. Interestingly, in a meta-analysis, XPC rs2228001 was significantly associated with an increased overall cancer risk, especially in Asian populations (40). However, in that study, the OR were not obvious, and 95\%CI were all near 1.00 (40). Thus, in the current study, although we examined up to about 1,900 cases, XPC rs2228001 seemed not to serve as a biomarker alone. It should interact with smoking or betel quid chewing, to be significant. It is of interest to investigate whether XPC rs2228001 can serve as a significant biomarker for these types of cancers in Taiwan in the near future.
It is frequently a difficult mission for SNP studies about the genotype-phenotype correlation, since the phenotypic samples are not easily available. Thus, the SNP studies seldom provide data from the angles of mRNA or protein levels. However, it is very helpful in revealing the biological meanings of these SNPs, extending our understanding of the personalized etiology of each oral cancer patient. In this study, with 35 samples collected form the oral cancer patients, we determined their expression of XPC at the mRNA and protein levels. The protein patterns showed that oral cancer patients with CC genotypes at XPC rs2228001 were of significant lower level than those with wild-type AA genotype (Figure 2B). Furthermore, a combination of AC plus CC genotypes at XPC rs2228001 was also higher than AA genotype (Figure 2C). Very possibly, a lower expression of protein was caused by the limited number of examined samples. Most valuably, we investigated the DNA repair capacity according to the various XPC rs2228001 genotypes. The results showed that people carrying $\mathrm{AC}$ and $\mathrm{CC}$ genotypes at XPC rs2228001 are of lower DNA repair capacity and thus may have higher risk in oral cancer (Figure $3)$. However, the samples we collected were from nonsmoking, non-alcohol and non-betel quid oral cancer patients. In the future, not only oral cancer patients, but also healthy individuals should be collected. Also, more samples as well as those collected from smokers, alcohol drinkers, and betel quid chewers and corresponding measurements are valuable to fully understanding the genotype-behavior correlation.

In conclusion, the study provides evidence that the $\mathrm{CC}$ genotype of XPC rs2228001 is associated with decreased 
DNA repair capacity, contribute to higher risk of oral cancer in Taiwan. Genotype prediction is useful for those smokers and betel quid chewers. Furthermore, genotype-phenotype studies would be very valuable to reveal the relationship between XPC and oral etiology.

\section{Conflicts of Interest}

All the Authors declare no conflicts of interest regarding this study with any company or any person.

\section{Authors' Contributions}

Research design was done by WCN and CWS. Patient and questionnaire summaries were provided by SLC and HTC. Experimental work was done by CWS, WYC, and YCC. Statistical analysis was done by LHT, $\mathrm{WZH}$, and MMC. TCW and BDT wrote the manuscript, whereas BDT reviewed it and are responsible for the revision.

\section{Acknowledgements}

The Authors are grateful to the Tissue-bank of China Medical University Hospital and doctors/nurses under Prof. Tsai MH's leadership for their excellent sample collection and survey assistance. They are, also, thankful for the technical assistance from Yu-Ting Chin, Tai-Lin Huang and Yu-Chen Hsiau. This study was supported mainly by the Taichung Veterans General Hospital (TCVGH-CTUST1097703) to Dr. Wu CN and Lee HT and partially by China Medical University Hospital and Asia University (CMU109-ASIA-05).

\section{References}

1 Siegel RL, Miller KD, Fuchs HE and Jemal A: Cancer statistics, 2021. CA Cancer J Clin 71(1): 7-33, 2021. PMID: 33433946. DOI: $10.3322 /$ caac. 21654

2 Taiwan Ministry of Health and Welfare Clinical Trial and Research Center of Excellence: Cancer registration annual report. Available at: https://www.hpa.gov.tw/Pages/List.aspx?nodeid=269 [Last accessed on March 29th, 2021]

3 Ko YC, Huang YL, Lee CH, Chen MJ, Lin LM and Tsai CC: Betel quid chewing, cigarette smoking and alcohol consumption related to oral cancer in Taiwan. J Oral Pathol Med 24(10): 450-453, 1995. PMID: 8600280. DOI: 10.1111/j.1600-0714.1995.tb01132.x

4 Friedberg EC: How nucleotide excision repair protects against cancer. Nat Rev Cancer 1(1): 22-33, 2001. PMID: 11900249. DOI: $10.1038 / 35094000$

5 Wood RD, Mitchell M, Sgouros J and Lindahl T: Human DNA repair genes. Science 291(5507): 1284-1289, 2001. PMID: 11181991. DOI: $10.1126 /$ science. 1056154

6 De Silva IU, McHugh PJ, Clingen PH and Hartley JA: Defining the roles of nucleotide excision repair and recombination in the repair of DNA interstrand cross-links in mammalian cells. Mol Cell Biol 20(21): 7980-7990, 2000. PMID: 11027268. DOI: 10.1128/mcb.20.21.7980-7990.2000

7 Goode EL, Ulrich CM and Potter JD: Polymorphisms in DNA repair genes and associations with cancer risk. Cancer Epidemiol Biomarkers Prev 11(12): 1513-1530, 2002. PMID: 12496039.
8 Sugasawa K, Ng JM, Masutani C, Iwai S, van der Spek PJ, Eker AP, Hanaoka F, Bootsma D and Hoeijmakers JH: Xeroderma pigmentosum group $\mathrm{C}$ protein complex is the initiator of global genome nucleotide excision repair. Mol Cell 2(2): 223-232, 1998. PMID: 9734359. DOI: 10.1016/s1097-2765(00)80132-x

9 Thoma BS and Vasquez KM: Critical DNA damage recognition functions of XPC-hHR23B and XPA-RPA in nucleotide excision repair. Mol Carcinog 38(1): 1-13, 2003. PMID: 12949838. DOI: $10.1002 / \mathrm{mc} .10143$

$10 \mathrm{Wu}$ X, Gu J, Grossman HB, Amos CI, Etzel C, Huang M, Zhang Q, Millikan RE, Lerner S, Dinney CP and Spitz MR: Bladder cancer predisposition: a multigenic approach to DNA-repair and cell-cycle-control genes. Am J Hum Genet 78(3): 464-479, 2006. PMID: 16465622. DOI: 10.1086/500848

11 Rouissi K, Bahria IB, Bougatef K, Marrakchi R, Stambouli N, Hamdi K, Cherif M, Ben Slama MR, Sfaxi M, Othman FB, Chebil M, Elgaaied AB and Ouerhani S: The effect of tobacco, XPC, ERCC2 and ERCC5 genetic variants in bladder cancer development. BMC Cancer 11: 101, 2011. PMID: 21426550. DOI: $10.1186 / 1471-2407-11-101$

12 Roberts MR, Shields PG, Ambrosone CB, Nie J, Marian C, Krishnan SS, Goerlitz DS, Modali R, Seddon M, Lehman T, Amend KL, Trevisan M, Edge SB and Freudenheim JL: Singlenucleotide polymorphisms in DNA repair genes and association with breast cancer risk in the web study. Carcinogenesis 32(8): 1223-1230, 2011. PMID: 21622940. DOI: 10.1093/carcin/bgr096

13 Engin AB, Karahalil B, Engin A and Karakaya AE: DNA repair enzyme polymorphisms and oxidative stress in a Turkish population with gastric carcinoma. Mol Biol Rep 38(8): 53795386, 2011. PMID: 21390502. DOI: 10.1007/s11033-011-0690-9

14 de Verdier PJ, Sanyal S, Bermejo JL, Steineck G, Hemminki K and Kumar R: Genotypes, haplotypes and diplotypes of three XPC polymorphisms in urinary-bladder cancer patients. Mutat Res 694(1-2): 39-44, 2010. PMID: 20887739. DOI: 10.1016/ j.mrfmmm.2010.09.003

15 Weiss JM, Weiss NS, Ulrich CM, Doherty JA, Voigt LF and Chen $\mathrm{C}$ : Interindividual variation in nucleotide excision repair genes and risk of endometrial cancer. Cancer Epidemiol Biomarkers Prev 14(11 Pt 1): 2524-2530, 2005. PMID: 16284373. DOI: 10.1158/1055-9965.EPI-05-0414

$16 \mathrm{Hu}$ Z, Wang Y, Wang X, Liang G, Miao X, Xu Y, Tan W, Wei Q, Lin D and Shen H: DNA repair gene XPC genotypes/haplotypes and risk of lung cancer in a Chinese population. Int J Cancer 115(3): 478-483, 2005. PMID: 15700316. DOI: 10.1002/ijc.20911

17 Lee GY, Jang JS, Lee SY, Jeon HS, Kim KM, Choi JE, Park JM, Chae MH, Lee WK, Kam S, Kim IS, Lee JT, Jung TH and Park JY: XPC polymorphisms and lung cancer risk. Int J Cancer 115(5): 807-813, 2005. PMID: 15729698. DOI: 10.1002/ ijc. 20900

18 Sakoda LC, Loomis MM, Doherty JA, Julianto L, Barnett MJ, Neuhouser ML, Thornquist MD, Weiss NS, Goodman GE and Chen C: Germ line variation in nucleotide excision repair genes and lung cancer risk in smokers. Int J Mol Epidemiol Genet 3(1): 1-17, 2012. PMID: 22493747.

19 Kietthubthew S, Sriplung $\mathrm{H}, \mathrm{Au} \mathrm{WW}$ and Ishida T: Polymorphism in DNA repair genes and oral squamous cell carcinoma in Thailand. Int J Hyg Environ Health 209(1): 21-29, 2006. PMID: 16373199. DOI: 10.1016/j.ijheh.2005.06.002

20 Wang Y, Spitz MR, Lee JJ, Huang M, Lippman SM and Wu X: Nucleotide excision repair pathway genes and oral premalignant 
lesions. Clin Cancer Res 13(12): 3753-3758, 2007. PMID: 17575242. DOI: 10.1158/1078-0432.CCR-06-1911

21 Senghore T, Chien HT, Wang WC, Chen YX, Young CK, Huang SF and Yeh CC: Polymorphisms in ERCC5 rs 17655 and ERCC1 rs735482 genes associated with the survival of male patients with postoperative oral squamous cell carcinoma treated with adjuvant concurrent chemoradiotherapy. J Clin Med 8(1): 33, 2019. PMID: 30609649 . DOI: $10.3390 /$ jcm8010033

22 Shih LC, Li CH, Sun KT, Chen LY, Hsu CL, Hung YW, Wu CN, Hsia TC, Shen TC, Chang WS, Shih TC, Tsai CW and Bau DT: Association of matrix metalloproteinase-7 genotypes to the risk of oral cancer in Taiwan. Anticancer Res 38(4): 2087-2092, 2018. PMID: 29599326. DOI: 10.21873/anticanres.12448

23 Tsai CW, Hsu HM, Wang YC, Chang WS, Shih LC, Sun KT, Hung YW, Yang YC, Gong CL and Bau DT: Contribution of $M M P 2$ promoter genotypes to oral cancer susceptibility, recurrence and metastasis in Taiwan. Anticancer Res 38(12): 6821-6826, 2018. PMID: 30504396. DOI: 10.21873/anticanres. 13055

24 Shih LC, Tsai CW, Sun KT, Hsu HM, Shen TC, Tsai YT, Chang WS, Lin ML, Wang YC, Gong CL and Bau DT: Association of caspase- 8 genotypes with oral cancer risk in Taiwan. In Vivo 33(4): 1151-1156, 2019. PMID: 31280204. DOI: 10.21873/ invivo. 11585

25 Chen GL, Wang SC, Shen TC, Chang WS, Lin C, Hsia TC, Bau DT and Tsai CW: Significant association of chitinase 3-like 1 genotypes to asthma risk in Taiwan. In Vivo 35(2): 799-803, 2021. PMID: 33622872. DOI: 10.21873/invivo.12320

26 Shih LC, Tsai CW, Chang WS, Shen TC, Wang YC, Yang JS, Lin ML, Wang ZH and Bau DT: Association of caspase-8 genotypes with the risk for nasopharyngeal carcinoma in Taiwan. Anticancer Res 40(10): 5503-5508, 2020. PMID: 32988873. DOI: 10.21873 /anticanres.14562

27 Shih LC, Chang WS, Lee HT, Wang YC, Wang ZH, Chao CY, Yu CC, Lin HY, Shen TC, Kuo CC, Tsai CW and Bau DT: Interaction of interleukin-16 genotypes with betel quid chewing behavior on oral cancer in Taiwan. In Vivo 34(4): 1759-1764, 2020. PMID: 32606144 . DOI: $10.21873 /$ invivo.11969

28 Lin CC, Chen KB, Tsai CH, Tsai FJ, Huang CY, Tang CH, Yang JS, Hsu YM, Peng SF and Chung JG: Casticin inhibits human prostate cancer DU 145 cell migration and invasion via Ras/Akt/NF-kB signaling pathways. J Food Biochem 43(7): e12902, 2019. PMID: 31353708. DOI: 10.1111/jfbc.12902

29 Liu SP, Shibu MA, Tsai FJ, Hsu YM, Tsai CH, Chung JG, Yang JS, Tang CH, Wang S, Li Q and Huang CY: Tetramethylpyrazine reverses high-glucose induced hypoxic effects by negatively regulating HIF-1 $\alpha$ induced BNIP3 expression to ameliorate H9c2 cardiomyoblast apoptosis. Nutr Metab (Lond) 17: 12, 2020. PMID: 32021640. DOI: 10.1186/s12986-020-0432-x

30 Lee H, Chen P, Wang S, Fong Y, Tsai C, Tsai F, Chung J, Huang C, Yang J, Hsu Y, Li T and Tang C: Plumbagin suppresses endothelial progenitor cell-related angiogenesis in vitro and in vivo. Journal of Functional Foods 52: 537-544, 2021. DOI: 10.1016/j.jff.2018.11.040
31 Huang CY, Chang WS, Tsai CW, Hsia TC, Shen TC, Bau DT and Shui HA: The contribution of interleukin-8 genotypes and expression to nasopharyngeal cancer susceptibility in Taiwan. Medicine (Baltimore) 97(36): e12135, 2018. PMID: 30200105. DOI: 10.1097/MD.0000000000012135

32 Wang SC, Chen SF, Lee YM, Chuang CL, Bau DT and Lin SS: Baicalin scavenges reactive oxygen species and protects human keratinocytes against UVC-induced cytotoxicity. In Vivo 27(6): 707-714, 2013. PMID: 24292572.

33 Malik SS, Zia A, Rashid S, Mubarik S, Masood N, Hussain M, Yasmin A and Bano R: XPC as breast cancer susceptibility gene: evidence from genetic profiling, statistical inferences and protein structural analysis. Breast Cancer 27(6): 1168-1176, 2020. PMID: 32562189. DOI: 10.1007/s12282-020-01121-z

34 Romanowicz H, Pyziak Ł, Jabłoński F, Bryś M, Forma E and Smolarz B: Analysis of DNA repair genes polymorphisms in breast cancer. Pathol Oncol Res 23(1): 117-123, 2017. PMID: 27571987. DOI: $10.1007 / \mathrm{s} 12253-016-0110-5$

35 Campayo M, Viñolas N, Navarro A, Carcereny E, Casas F, Gel B, Diaz T, Gimferrer JM, Marrades RM, Ramirez J and Monzo M: Single nucleotide polymorphisms in tobacco metabolism and DNA repair genes and prognosis in resected non-small-cell lung cancer. J Surg Res 167(1): e5-12, 2011. PMID: 21324488. DOI: 10.1016/j.jss.2011.01.007

36 Sakano S, Hinoda Y, Sasaki M, Wada T, Matsumoto H, Eguchi S, Shinohara A, Kawai Y, Hara T, Nagao K, Hara T, Naito K and Matsuyama $\mathrm{H}$ : Nucleotide excision repair gene polymorphisms may predict acute toxicity in patients treated with chemoradiotherapy for bladder cancer. Pharmacogenomics 11(10): 1377-1387, 2010. PMID: 21047201. DOI: 10.2217/pgs.10.106

37 Hua RX, Zhu J, Jiang DH, Zhang SD, Zhang JB, Xue WQ, Li XZ, Zhang PF, He J and Jia WH: Association of XPC gene polymorphisms with colorectal cancer risk in a southern Chinese population: a case-control study and meta-analysis. Genes (Basel) 7(10): 73, 2016. PMID: 27669310. DOI: 10.3390/genes7100073

38 Yan Y, Xu J, Xu B, Wen Q, Zhou J, Zhang L, Zuo L, Lv G and Shi Y: Effects of Xeroderma pigmentosum group C polymorphism on the likelihood of prostate cancer. J Clin Lab Anal 34(9): e23403, 2020. PMID: 32488882. DOI: 10.1002/jcla.23403

39 Liu J, Sun L, Xu Q, Tu H, He C, Xing C and Yuan Y: Association of nucleotide excision repair pathway gene polymorphisms with gastric cancer and atrophic gastritis risks. Oncotarget 7(6): 6972-6983, 2016. PMID: 26760766. DOI: 10.18632/oncotarget.6853

$40 \mathrm{He}$ J, Shi TY, Zhu ML, Wang MY, Li QX and Wei QY: Associations of Lys939Gln and Ala499Val polymorphisms of the XPC gene with cancer susceptibility: a meta-analysis. Int J Cancer 133(8): 1765-1775, 2013. PMID: 23400628. DOI: $10.1002 / \mathrm{ijc} .28089$

Received April 2, 2021

Revised April 10, 2021 Accepted April 14, 2021 